\title{
The Impact of Variable Curing Conditions on the Properties and Microstructures of Mixtures of Ground Granulated Blast Furnace Slag and Circulating Q1 Fluidized Bed Combustion Ash
}

Shao-Heng Hsieh

Department of Harbor and River Engineering, National Taiwan Ocean University, Keelung City 20224, Taiwan (R.O.C.), 20152002@ntou.edu.tw

Wei-Chung Yeih

Department of Harbor and River Engineering, National Taiwan Ocean University, Keelung City, Taiwan (R.O.C.)

Ran Huang

Department of Harbor and River Engineering, National Taiwan Ocean University, Keelung City, Taiwan (R.O.C.)

Follow this and additional works at: https://jmstt.ntou.edu.tw/journal

Part of the Fresh Water Studies Commons, Marine Biology Commons, Ocean Engineering Commons, Oceanography Commons, and the Other Oceanography and Atmospheric Sciences and Meteorology Commons

\section{Recommended Citation}

Hsieh, Shao-Heng; Yeih, Wei-Chung; and Huang, Ran (2021) "The Impact of Variable Curing Conditions on the Properties and Microstructures of Mixtures of Ground Granulated Blast Furnace Slag and Circulating Q1 Fluidized Bed Combustion Ash," Journal of Marine Science and Technology. Vol. 29: Iss. 5, Article 2.

DOI: $10.51400 / 2709-6998.2463$

Available at: https://jmstt.ntou.edu.tw/journal/vol29/iss5/2

This Research Article is brought to you for free and open access by Journal of Marine Science and Technology. It has been accepted for inclusion in Journal of Marine Science and Technology by an authorized editor of Journal of Marine Science and Technology. 


\title{
The Impact of Variable Curing Conditions on the Properties and Microstructures of Mixtures of Ground Granulated Blast Furnace Slag and Circulating Fluidized Bed Combustion Ash
}

\author{
Shao-Heng Hsieh*, Wei-Chung Yeih, Ran Huang
}

Department of Harbor and River Engineering, National Taiwan Ocean University, No.2, Beining Rd., Zhongzheng Dist., Keelung City, 20224, Taiwan, ROC

\begin{abstract}
The use of Portland cement, an important construction material, is encountering growing challenges because of its adverse environmental impacts. In this study, a new hydration system without Portland cement, which blends ground granulated blast furnace slag (GGBFS) and circulating fluidized bed combustion (CFBC) ash, was developed and tested. The variables included the effect of different types of CFBC ash, the mass ratios between CFBC ash and GGBFS, and different curing temperatures. The mortar properties were determined through the compressive strength test, absorption test, shrinkage test, X-ray diffraction, scanning electron microscopy, and energy-dispersive X-ray spectroscopy. The main results were as follows: (1) The compressive strength of mortar specimens made with this ecologically friendly hydration system reached at least $40 \mathrm{MPa}$ under a $35{ }^{\circ} \mathrm{C}$ curing temperature. (2) Mortar with finer CFBC ash as an activator had higher compressive strength and lower absorption. (3) A proper mass ratio of GGBFS to CFBC ash is necessary for engineering applications. The present findings indicate that to maximize compressive strength, the particle size and the mass ratio of CFBC ash to GGBFS must be considered. According to the result, the type A ash with 3:7 mass ratio of CFBC ash to GGBFS is recommended.
\end{abstract}

Keywords: Ground granulated blast furnace slag, Circulating fluidized bed combustion, Ecologically friendly hydration system, Curing temperature

\section{Introduction}

S ustainable development is in the spotlight of construction industry development. As environmental awareness grows, research on and the development of construction materials increasingly focuses on reducing carbon dioxide emissions and saving energy in production. An effective method to reduce the consumption of natural materials and fossil fuel energy involves reusing or recycling various types of industry waste. Sustainable concrete use can be achieved through the addition of supplementary cementitious materials to Portland cement. The use of Portland cement, an important construction material, is facing growing challenges because of its adverse environmental impacts $[19,29]$. Alkali-activated materials (AAMs) are recognized as potential alternatives to Portland cement, and it could save more energy and reduce more carbon emission compared with Portland cement $[9,12,35]$. The alkali activation process of AAMs will improve the strength of cement mortars; moreover, there are common AAMs such as ground granulated blast furnace slag and coal fly ash [24]. Ground granulated blast furnace slag (GGBFS), a steel byproduct, is a potential alternative to Portland

Received 1 September 2020; revised 15 October 2020; accepted 22 April 2021.

Available online 18 November 2021.

* Corresponding author.

E-mail addresses: 20152002@ntou.edu.tw (S.-H. Hsieh), wcyeih@mail.ntou.edu.tw (W.-C. Yeih), ranhuang@mail.ntou.edu.tw (R. Huang). 
cement, over which it has the following advantages: it conserves natural resources [29], reduces waste generation [34], and reduces $\mathrm{CO}_{2}$ emissions and energy consumption [14,18,32].

As defined by the American Concrete Institute, granulated blast furnace slag is a glassy, granular material formed when molten blast furnace slag is rapidly chilled, as by immersion in water. As its name implies, GGBFS is a hydraulic cement [1] made by finely grinding granulated blast furnace slag. Usually, the compositional formula of GGBFS is $\mathrm{C}_{5} \mathrm{~S}_{3} \mathrm{~A}$, in which three main oxides are fairly equally distributed: $\mathrm{CaO}(\mathrm{C}), \mathrm{SiO}_{2}$ (S), and $\mathrm{Al}_{2} \mathrm{O}_{3}$ (A). The stoichiometric formulas for the GGBFS hydration process in different environments are as follows [36]:

- In water

$$
\begin{aligned}
& \mathrm{C}_{5} \mathrm{~S}_{3} \mathrm{~A}+12 \mathrm{H}_{2} \mathrm{O} \rightarrow \frac{1}{3} \mathrm{C}_{4} A H_{13}+\frac{7}{3} \mathrm{C}-\mathrm{S}-\mathrm{H} \\
& +\frac{2}{3} \mathrm{C}_{2} \mathrm{ASH}_{8}
\end{aligned}
$$

- In $\mathrm{Ca}(\mathrm{OH})_{2}$ solution

$$
\mathrm{C}_{5} \mathrm{~S}_{3} \mathrm{~A}+2 \mathrm{CaO}+16 \mathrm{H}_{2} \mathrm{O} \rightarrow \mathrm{C}_{4} \mathrm{AH}_{13}+3 \mathrm{C}-\mathrm{S}-\mathrm{H}
$$

Calcium silicate hydrate $(\mathrm{C}-\mathrm{S}-\mathrm{H})$ gel, the main hydration product, is the principal source of strength. Although similar to Portland cement, GGBFS is less reactive. It is difficult to hydrate because it generates a less permeable layer, the pseudomorphic layer, when interacting with water. The lower alkalinity, fewer ionic bonds, more covalent bonds, and dense structure of GGBFS mean that it lacks the polarity to break down the chemical bonds in the pseudomorphic layer. However, this layer can be broken in alkaline conditions. Some activators such as metasilicate and sodium hydroxide can be added to facilitate GGBFS hydration $[6,27]$. The activation process of GGBFS depends on alkali liquor $[8,21]$ or industrial wastes such as wasted glass, rice ash, natural zeolite and paper ash $[20,25,30,37]$. According to the activator, the production of activated GGBFS will be different: when $\mathrm{Na}^{+}$and $\mathrm{Al}^{3+}$ (or silica ion) are present, the activation process will produce zeolite-like structures; in contrast, when $\mathrm{Na}^{+}$and $\mathrm{Al}^{3+}$ (or silica ion) are absent, the dissolved activator will emit $\mathrm{OH}^{-}$, increase $\mathrm{pH}$, break the impermeable layer and produce $\mathrm{C}-\mathrm{S}-\mathrm{H}$ gel [10]. Circulating fluidized bed combustion (CFBC) ash is a newly identified activator for GGBFS. CFBC equipment has numerous advantages over conventional boilers: higher space efficiency and combustion efficiency, lower combustion temperature, lower NOx and SOx emissions, and better compatibility with various fuels. This equipment can combust low-grade coal, oil coke, biomass, sludge, waste plastics, and waste tires. Notably, the characteristics and quality of CFBC ash varies with fuel type [26], with some types potentially serving as binders or activators. Table 1 shows the chemical composition of various types of CFBC ash [23]. In the CFBC process, limestone is used as the desulfurizer, which explains the presence of calcium sulfate and free calcium oxide in the reactant. Calcium oxide constitutes a major component of CFBC ash $[2,7,31]$. When CFBC ash is dissolved in water, $\mathrm{CaO}$ hydrates, producing $\mathrm{Ca}(\mathrm{OH})_{2}$ and releasing $\mathrm{OH}^{-}$. This causes the solution to become alkaline ( $\mathrm{pH}$ 11.5-12.5), breaking down the holohyaline structure of GGBFS. $\mathrm{Ca}(\mathrm{OH})_{2}$ then reacts with active chemicals such as $\mathrm{SiO}_{2}$ and $\mathrm{Al}_{2} \mathrm{O}_{3}$, producing $\mathrm{C}-\mathrm{S}-\mathrm{H}$ gel $[17,22,28]$. As a binder, the $\mathrm{CaSO}_{4}$ in CFBC ash reacts with water to produce $\mathrm{CaSO}_{4} \cdot 2 \mathrm{H}_{2} \mathrm{O}$, which also contributes to the strength of concrete [13,33]. Several studies have indicated that additional approaches can be used to expedite the dissolution and hydration of activator materials and improve the strength development of mortar

\begin{tabular}{|c|c|c|c|c|c|}
\hline \multirow[t]{2}{*}{ Chemical } & \multirow{2}{*}{$\frac{\text { Conventional combustion }}{\text { Fly ash }}$} & \multicolumn{4}{|c|}{ Fuel of Circulating fluidized bed combustion } \\
\hline & & low-grade coal & high-grade coal & oil coke & waste tires, etc \\
\hline $\mathrm{SiO}_{2}$ & 52.0 & 41.7 & 24.8 & 3.0 & 20.8 \\
\hline $\mathrm{Al}_{2} \mathrm{O}_{3}$ & 24.5 & 33.6 & 15.1 & nil & 23.6 \\
\hline $\mathrm{TiO}_{2}$ & Nil & 1.9 & 0.7 & Nil & 2.9 \\
\hline $\mathrm{Fe}_{2} \mathrm{O}_{3}$ & 4.7 & 3.5 & 3.5 & 0.1 & 3.3 \\
\hline $\mathrm{CaO}$ & 11.5 & 14.9 & 19.2 & 54.0 & 26.8 \\
\hline $\mathrm{f}-\mathrm{CaO}$ & Nil & 12.5 & 14.0 & 21.5 & 16.3 \\
\hline $\mathrm{MgO}$ & 1.3 & 0.9 & 0.5 & 2.5 & 4.3 \\
\hline $\mathrm{SO}_{3}$ & 0.3 & 3.4 & 7.4 & 41.9 & 4.8 \\
\hline $\mathrm{Na}_{2} \mathrm{O}$ & 2.0 & 0.2 & nil & nil & 2.2 \\
\hline $\mathrm{K}_{2} \mathrm{O}$ & 1.98 & 0.8 & 1.5 & nil & 1.2 \\
\hline
\end{tabular}
specimens. For example, the activator particles can

Table 1. Chemical compositions different type of CFBC ashes and fly ash (wt.\%) (Li et al., 2010). 
Table 2. Physical and chemical characteristics of GGBFS.

\begin{tabular}{|c|c|c|c|}
\hline \multirow[t]{5}{*}{$\begin{array}{l}\text { Physical } \\
\text { properties }\end{array}$} & $\begin{array}{l}\text { Specific surface } \\
\left(\mathrm{m}^{2} / \mathrm{kg}\right)\end{array}$ & & 585.0 \\
\hline & $\begin{array}{l}\text { Retain \#325 } \\
\text { sieve \% }\end{array}$ & & 0.7 \\
\hline & Specific gravity & & 2.88 \\
\hline & Activity index & 7 -days (\%) & 102.7 \\
\hline & & 28 -days $(\%)$ & 125.3 \\
\hline \multirow{8}{*}{$\begin{array}{l}\text { Chemical } \\
\text { composition }\end{array}$} & LOI (wt\%) & & 0.0 \\
\hline & $\mathrm{SiO}_{2}\left(w \mathrm{t}^{\%} \%\right)$ & & 34.2 \\
\hline & $\mathrm{Al}_{2} \mathrm{O}_{3}(w \mathrm{t} \%)$ & & 14.2 \\
\hline & $\mathrm{FeO}(w \mathrm{t} \%)$ & & 0.2 \\
\hline & $\mathrm{CaO}(w \mathrm{t} \%)$ & & 40.0 \\
\hline & $\operatorname{MgO}\left(w t^{0} \%\right)$ & & 7.9 \\
\hline & $\mathrm{SO}_{3}(\mathrm{wt} \%)$ & & 0.2 \\
\hline & Alkalinity & & 1.8 \\
\hline
\end{tabular}

be more finely ground, and the mortar specimens can be heated during curing [22].

In the present study, the properties of mortar specimens made with GGBFS and CFBC ash were explored. Because no Portland cement is used, the combination of GGBFS and CFBC ash can be regarded as a cementless, ecologically friendly hydration system. In relevant studies, CFBC ash has been used mainly to replace cement as an auxiliary cementitious material for concrete. In the present study, CFBC ash was used as an activator to stimulate the hydration of GGBFS without the use of cement. The engineering properties of mortar using GGBFS, rice husk ash, and CFBC ash (SRF) binder have been investigated [15]. Properties of mortar formed from a mixture of GGBFS, waste brick powder, and ceramic have been investigated [16]. The strengths of these above-mentioned systems are lower than those using Portland cement. In the present study, a rapid increase in strength for mortar made with GGBFS and CFBC ash was achieved simply by increasing the curing temperature

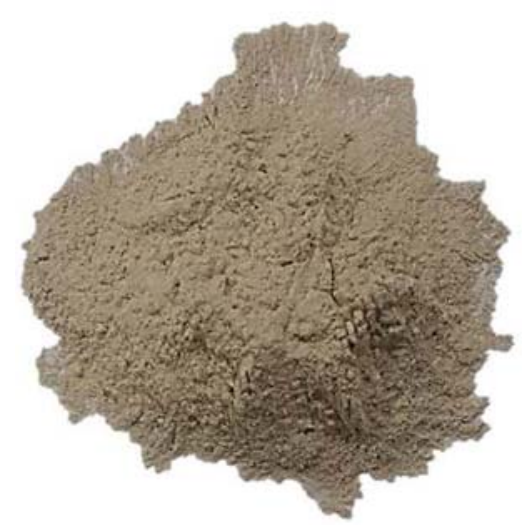

(a) to $35{ }^{\circ} \mathrm{C}$. These findings cast a light on this combination as a potential precast alternative in the concrete industry.

\section{Materials and methods}

\subsection{Materials}

\subsubsection{GGBFS}

The GGBFS was provided by the CHC Resources Corporation (Taiwan). Table 2 presents its physicochemical characteristics.

\subsubsection{CFBC ash}

The CFBC ash was produced at the No. 6 Naphtha Cracker Complex Refinery Facility of Formosa Petrochemical Corporation (Taiwan). As shown in Fig. 1, two types of CFBC ash, which are byproducts from oil coke combustion, were used: type A ash, a yellowish white powder, and type B ash, a grayish white partial agglomeration. Both ash types passed the \#30 sieve. The nominal maximum aggregate size for type A and B ash were 75 and $600 \mu \mathrm{m}$, respectively. Tables 3 and 4 present their physical and chemical properties and compositions, respectively, as analyzed by X-ray fluorescence.

\subsubsection{Fine aggregate}

The fine aggregate used was gravelly sand from Hualien, Taiwan. The fineness modulus, specific weight, and saturated-surface-dry absorption were $3.07,2.63$, and $2.51 \%$, respectively.

\subsection{Testing variables and methods}

The testing variables were comprised of the CFBC ash type, GGBFS amount, and curing temperature. The three mixture codes are listed in Table 5. The

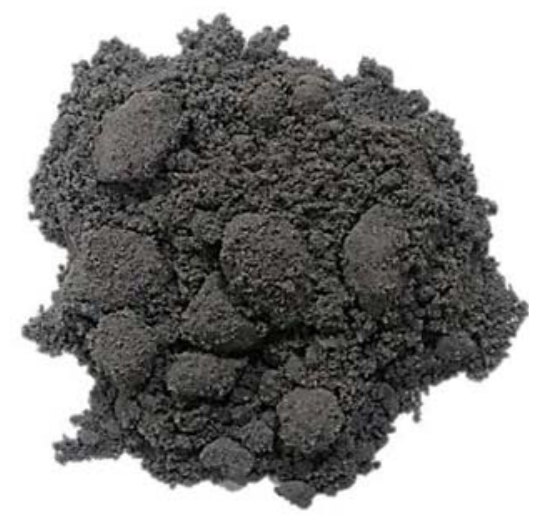

(b)

Fig. 1. CFBC ash appearance: (a) Type A (b) Type B. 
Table 3. Physical properties of CFBC ashes.

\begin{tabular}{lll}
\hline & Type A & Type B \\
\hline Specific gravity & 2.8 & 1.9 \\
Pass \#100 sieve (\%) & 99.8 & 28.4 \\
Pass \#200 sieve (\%) & 71.0 & 1.6 \\
Fineness $\left(\mathrm{m}^{2} / \mathrm{kg}\right)$ & 2535.9 & 737.1 \\
\hline
\end{tabular}

Table 4. Chemical compositions of CFBC ashes (wt.\%).

\begin{tabular}{lll}
\hline Chemical & Type A & Type B \\
\hline $\mathrm{CaO}$ & 43.9 & 49.5 \\
$\mathrm{Al}_{2} \mathrm{O}_{3}$ & 0.4 & 0.4 \\
$\mathrm{SiO}_{2}$ & 2.9 & 2.8 \\
$\mathrm{SO}_{3}$ & 30.3 & 13.2 \\
$\mathrm{Fe}_{2} \mathrm{O}_{3}$ & 0.5 & 0.6 \\
$\mathrm{MgO}$ & 0.5 & 0.8 \\
\hline
\end{tabular}

first, second, and third codes represent the type of CFBC ash, the ratio of CFBC ash to total solid powder (GGBFS + CFBC ash), and curing temperature, respectively.

The mix design used is explained as follows: First, the water-solid ratio and water-binder ratio were fixed at 0.22 and 0.30 , respectively. The 0.22 watersolid ratio was the lowest value to keep mixing process available (that is when the water-solid ratio is lower than 0.22 , the mixing process becomes impossible using mortar mixer), which is determined using trial and error method by changing the volume of fine aggregate under water-binder ratio of 0.3 . This water-binder ratio was determined by the preliminary experiment, which exhibited that the optimal strength and workability would occur when water-binder ratio was 0.3. Before the experiment of CFBC ashes, the proportion of GGBFS, water and fine aggregate was determined under fixed water-binder ratio 0.30 . The raw materials in $1 \mathrm{~m}^{3}$ mortar were $387.6,1292.1$, and $430.7 \mathrm{~kg}$ for water, GGBFS, and sand, respectively. Next, for the experiment of type A CFBC ash, the type A CFBC ash will be used as a partial substitute for GGBFS by

Table 5. Mixture code.

\begin{tabular}{llll}
\hline code & Condition & Label & Comments \\
\hline 1 & CFBC ash type & A & Type A \\
& & B & Type B \\
2 & CFBC ash/(CFBC & 3 & $3 / 10$ \\
& ash + GGBFS) & 4 & $4 / 10$ \\
& (by mass) & 5 & $5 / 10$ \\
& & 6 & $6 / 10$ \\
& & 7 & $7 / 10$ \\
3 & Curing temperature & N & $8 / 10$ \\
& & E & $23^{\circ} \mathrm{C}$ curing \\
& & & $35^{\circ} \mathrm{C}$ curing \\
\hline
\end{tabular}

Table 6. Constituents of mortar specimens $\left(\mathrm{kg} / \mathrm{m}^{3}\right)$.

\begin{tabular}{lllll}
\hline Mix Code. & Water & CFBC & GGBFS & Sand \\
\hline A3N & 387.6 & 387.6 & 904.5 & 430.7 \\
A4N & 387.6 & 516.8 & 775.2 & 430.7 \\
A5N & 387.6 & 646.0 & 646.0 & 430.7 \\
A3E & 387.6 & 387.6 & 904.4 & 430.7 \\
A4E & 387.6 & 516.8 & 775.2 & 430.7 \\
A5E & 387.6 & 646.0 & 646.0 & 430.7 \\
A6E & 387.6 & 775.2 & 516.8 & 430.7 \\
A7E & 387.6 & 904.4 & 387.6 & 430.7 \\
A8E & 387.6 & 1033.6 & 258.4 & 430.7 \\
B3E & 362.4 & 362.4 & 845.8 & 402.7 \\
B4E & 354.8 & 473.0 & 709.5 & 394.2 \\
B5E & 347.4 & 579.0 & 579.0 & 386.0 \\
\hline
\end{tabular}

equivalent weight substitution method; note that, in the cases of type A CFBC ash, using equivalent weight substitution method did not affect the volume proportion significantly because the specific weight between type A CFBC ash and GGBFS are almost the same. Although the equivalent weight substitution method works well in cases using type A CFBC ash, it has some problem when applied to type B CFBC ash. The specific weight between type $B$ CFBC ash and GGBFS are very different; the specific weight of type $B$ CFBC ash is much lower than GGBFS.

Therefore, for type B CFBC ash, the constituents of the mortars are revised and listed in Table 6 to meet the $1 \mathrm{~m}^{3}$ volume. However, the original design of mix proportion will cause different fine aggregate-binder ratios especially for those using type $B$ CFBC ash (the fine agrregate-binder ratios for specimens using type A CFBC ash are almost the same); it is then incorrect to compare the shrinkages on mortars made with type B CFBC ash with others.

\subsection{Specimens and testing details}

Studies have indicated that $\mathrm{pH}$ increases from 7 to 12.5 when CFBC dissolves in water (Poon et al., 2001, Lee et al., 2003, Jeong et al., 2016). Before the tests were conducted, the appropriate mixing time was determined. Samples with various ratios of CFBC and GGBFS were prepared. CFBC ash was first added to water, and the $\mathrm{pH}$ values were recorded. As shown in Fig. 2, approximately $30 \mathrm{~s}$ after incorporation with water, all mixtures attained a $\mathrm{pH}$ value between 12.85 and 12.93 . The mixing process in the present study was designed accordingly as follows:

(1) Add water to the mortar mixer. (2) Add the CFBC ash and stir the mixture at low speed $(140 \pm 5 \mathrm{rpm})$ for $30 \mathrm{~s}$ (3) Add the GGBFS and mix at low speed for an additional $30 \mathrm{~s}$ (4) Add the fine 


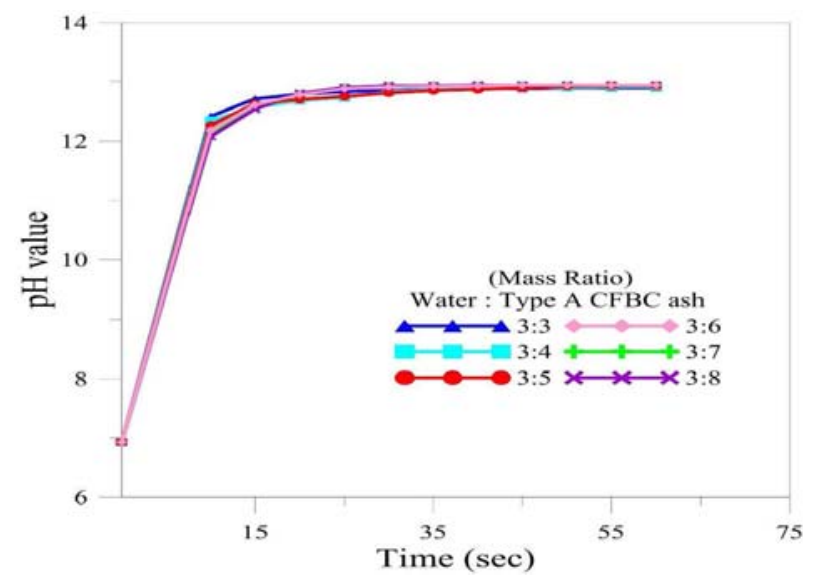

Fig. 2. The changes of $\mathrm{pH}$ value as stirring time varies.

aggregate and mix at low speed for $30 \mathrm{~s}$ and then at medium speed $(285 \pm 10 \mathrm{rpm})$ for $60 \mathrm{~s}$. After casting, the samples were immediately placed in chambers at $23{ }^{\circ} \mathrm{C}$ and $35{ }^{\circ} \mathrm{C}$. Relative humidity was maintained between $50 \%$ and $60 \%$.

Three cubic specimens $\left(50 \times 50 \times 50 \mathrm{~mm}^{3}\right)$ were cured for 1, 3, 7, 14, and 28 days. Afterward, the compressive strengths of the mortars were determined according to [5]. The specimens were placed in surface-dry conditions, and the surface in contact with the bearing block of the compressor was cleaned. The compressor loading rate was set to 900-1800 N/s. Three cylindrical specimens with a diameter of $100 \mathrm{~mm}$ and a height of $200 \mathrm{~mm}$ were cured for 28 days. Mortar absorption was tested according to [4]. Specimen weight was determined after $24 \mathrm{~h}$ of oven drying. Mortar shrinkage was examined according to ASTM International standard C596-09 [3]. Three rectangular specimens $\left(25 \times 25 \times 285 \mathrm{~mm}^{3}\right)$ were made and placed in a

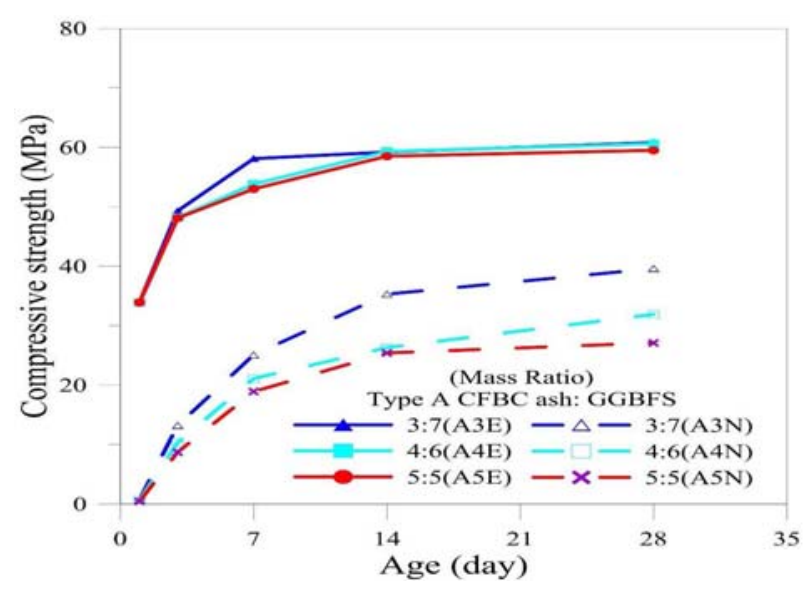

Fig. 3. Effect of curing temperature on the compressive strength of specimen.
Table 7. Compressive strength ( $\mathrm{MPa})$.

\begin{tabular}{llllll}
\hline Mixture Code & 1-day & 3-day & 7-day & 14-day & 28-day \\
\hline A3E & 33.9 & 49.3 & 58.1 & 59.2 & 60.8 \\
A4E & 33.9 & 48.2 & 53.8 & 59.3 & 60.6 \\
A5E & 33.9 & 48.1 & 53.0 & 58.5 & 59.5 \\
A3N & 0.7 & 13.2 & 25.1 & 35.3 & 39.6 \\
A4N & 0.6 & 10.3 & 21.1 & 26.3 & 31.9 \\
A5N & 0.4 & 8.7 & 18.9 & 25.4 & 27.1 \\
A6E & 29.1 & 45.9 & 50.1 & 50.3 & 50.4 \\
A7E & 19.1 & 34.8 & 40.8 & 40.8 & 40.9 \\
A8E & 14.5 & 25.5 & 32.5 & 32.5 & 32.6 \\
B3E & 18.2 & 24.0 & 25.4 & 28.4 & 32.1 \\
B4E & 13.3 & 18.2 & 25.0 & 28.8 & 29.9 \\
B5E & 10.6 & 16.4 & 22.3 & 22.4 & 23.8 \\
\hline
\end{tabular}

$35{ }^{\circ} \mathrm{C}$ chamber at $50 \%$ relative humidity. After $22 \pm 2 \mathrm{~h}$, they were demolded. Their lengths were measured and designated as the initial lengths. After 3, 7, 14, 21, and 28 days under good curing conditions, their lengths were measured again to determine specimen shrinkage.

To investigate the strength development of the CFBC ash and GGBFS mixtures, the hydration reaction was assessed. The type $A$ ash specimens were prepared with a 0.3 water-binder ratio and were cured under $35{ }^{\circ} \mathrm{C}$ and at $50 \%-60 \%$ relative humidity for $24 \mathrm{~h}$. The compressive strengths of the samples aged for 7,14 , and 28 days were 1.62, 3.24, and $3.53 \mathrm{MPa}$, respectively. This indicates that the $\mathrm{CaSO}_{4}$ in CFBC ash reacted with water to produce $\mathrm{CaSO}_{4} \cdot 2 \mathrm{H}_{2} \mathrm{O}$. $\mathrm{C}-\mathrm{S}-\mathrm{H}$ gel, the main hydration product in the mixture of CFBC ash and GGFBS, had a considerably stronger phase-forming component than did $\mathrm{CaSO}_{4} \cdot 2 \mathrm{H}_{2} \mathrm{O}$. Therefore, CFBC alone and $\mathrm{CFBC}+\mathrm{GGBFS}$ were two different binder systems.

\section{Results and discussion}

\subsection{Compressive strength}

Figure 3 shows the compressive strengths of all mixtures. Table 7 presents the effect of curing temperature on compressive strength when type A ash was used. Regardless of curing time, the compressive strength increased with curing temperature. Huynh et al. (2018) reported that the compressive strength of mortar made from $30 \%$ CFBC ash and 70\% GGBFS reached 30-40 $\mathrm{MPa}$ after 120 days. In the present study, when the curing temperature increased from $25{ }^{\circ} \mathrm{C}$ to $35{ }^{\circ} \mathrm{C}$, the compressive strength of the mortar reached 33.7 and $60.8 \mathrm{MPa}$ after 1 and 28 days of curing, respectively. This demonstrates that increasing the curing temperature not only effectively reduces the curing time but also facilitates the development of compressive 


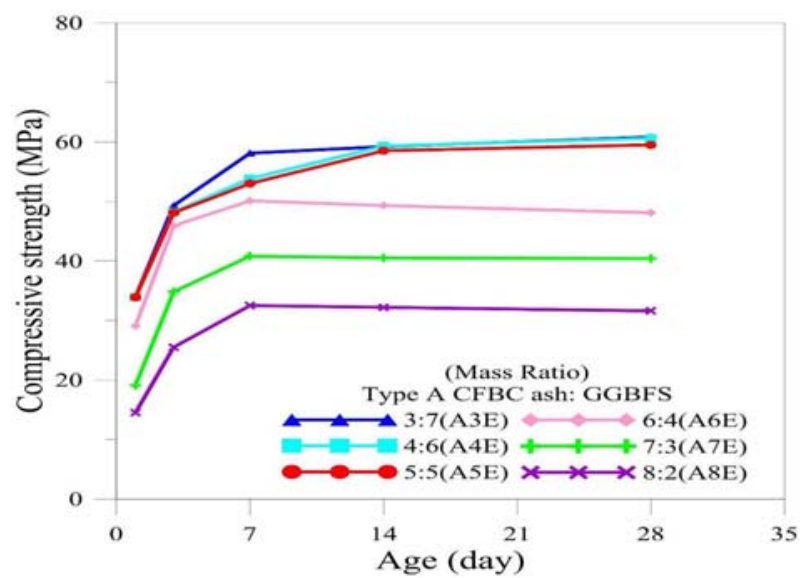

Fig. 4. Compressive strength of mortar specimen with Type A CFBC ash specimen.

strength. The compressive strength of the mortars in the present study were approximately double or triple that of the mortars developed by Lee et al. (2003). Notably, a higher curing temperature resulted in a higher chemical reaction rate. As an activator, CFBC ash dissolves faster under higher temperatures to accelerate the chemical reaction by which $\mathrm{C}-\mathrm{S}-\mathrm{H}$ gel and alumina, ferric oxide, trisulfate (AFt) are produced, which benefit strength development $[6,27]$.

Figures 4 and 5 show the compressive strengths of the mortar specimens made with type A and type B ash, respectively. When the same proportion of ash was used, the compressive strength of the type A ash specimen was higher than that of the type B ash specimen. This can probably be attributed to the particle size effect. Specifically, type A ash was a powder, whereas type $B$ ash had a partial

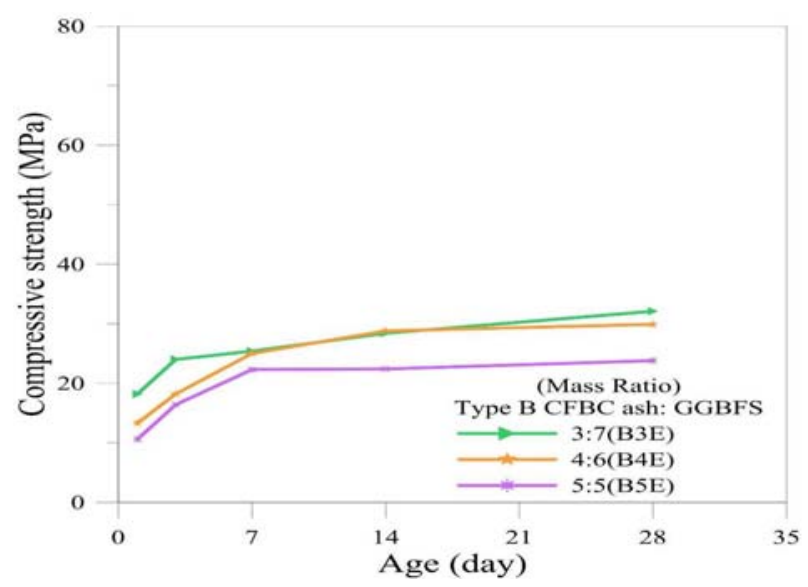

Fig. 5. Compressive strength of mortar specimen with Type B CFBC ash specimen.

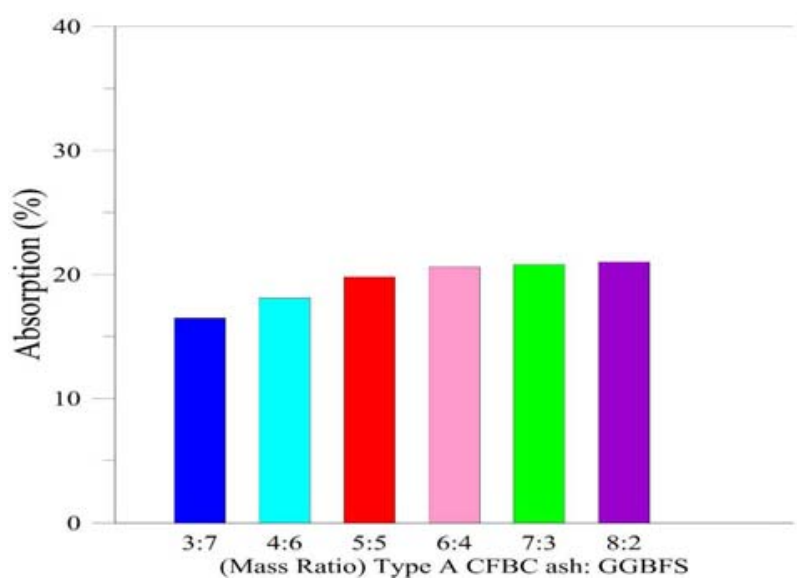

Fig. 6. Absorption of Type A CFBC ash mortar specimen with various ratios.

agglomeration. Type A ash had a larger specific surface area than type B ash. Therefore, the type A ash dissolved and reacted more quickly and completely than did the type $\mathrm{B}$ ash in the hydration process. The effect of the amount of CFBC ash in the mixtures was also tested, revealing that the addition of more ash led to reductions in compressive strength. A comparison of the compressive strengths of the different mixtures indicated that the mechanical properties of the self-hardening products in the CFBC ash were negligible. In other words, adding an excessive amount of activator does not promote binding and may even adversely affect strength development because the activator contains sulfate, which is conducive to AFt formation. Notably, the expansive properties of AFt may be harmful to $\mathrm{C}-\mathrm{S}-\mathrm{H}$ gel, especially in the case of $\mathrm{AFt}$ formed in the late stages.

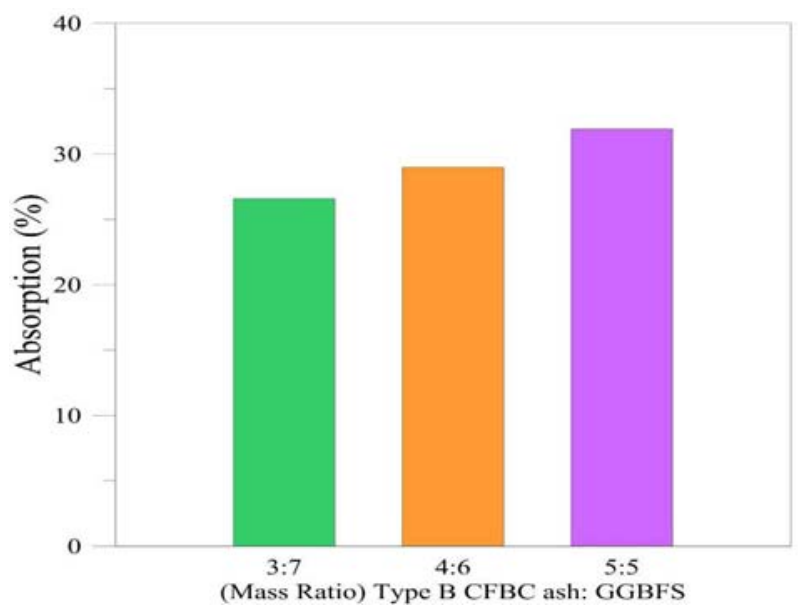

Fig. 7. Absorption of Type B CFBC ash mortar specimen with various ratios. 


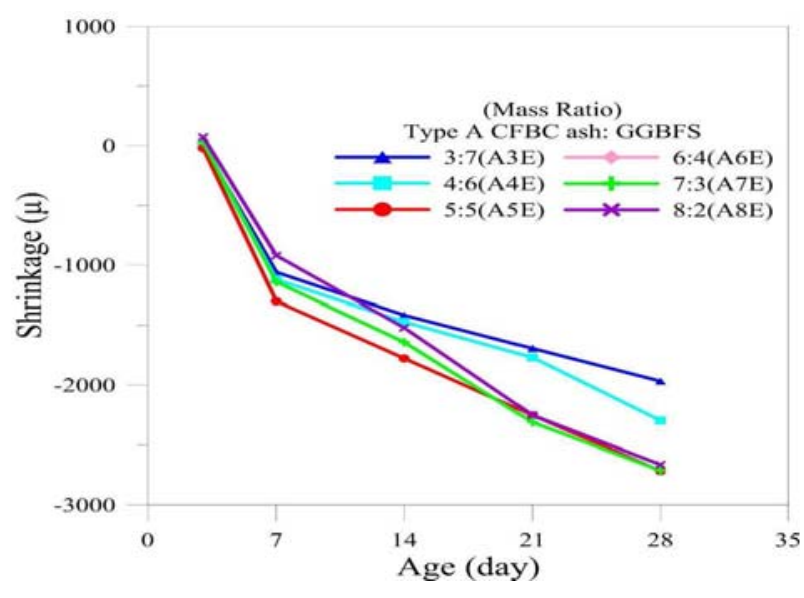

Fig. 8. Shrinkage strain of Type A CFBC ash mortar specimen.

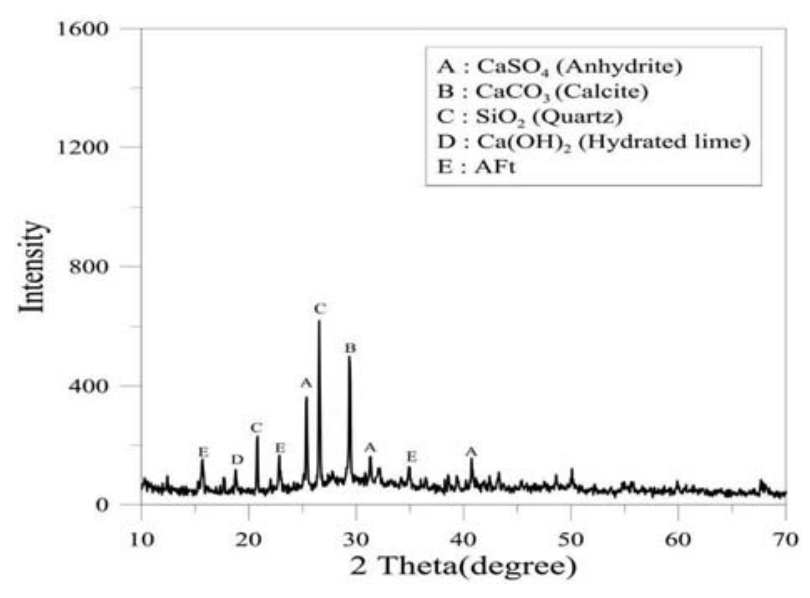

Fig. 9. XRD pattern of A3E mixture.

\subsection{Absorption}

The absorption test results are presented in Figs. 6 and 7. The mortar specimens made with type A ash had lower absorption rates than those made with type B ash because of differences in particle size. Specifically, when the same proportion of ash were used, the absorption rates of mortar specimens made with type A and type B ash after 28 days of curing were approximately $16 \%-21 \%$ and $26 \%-$ $32 \%$, respectively. Overall, considerable differences in absorption were observed between mortar made with fine- and coarse-particulate ash. As mentioned, type A ash reacted more quickly and completely as an activator than type $B$ ash did. The lower absorption of the mortar made with type A ash is ascribable to the fact that the volume of the voids found in those samples was smaller. Furthermore, absorption increased as more CFBC ash was added; because of the poor self-hardening properties of CFBC ash, adding a large amount of activator was

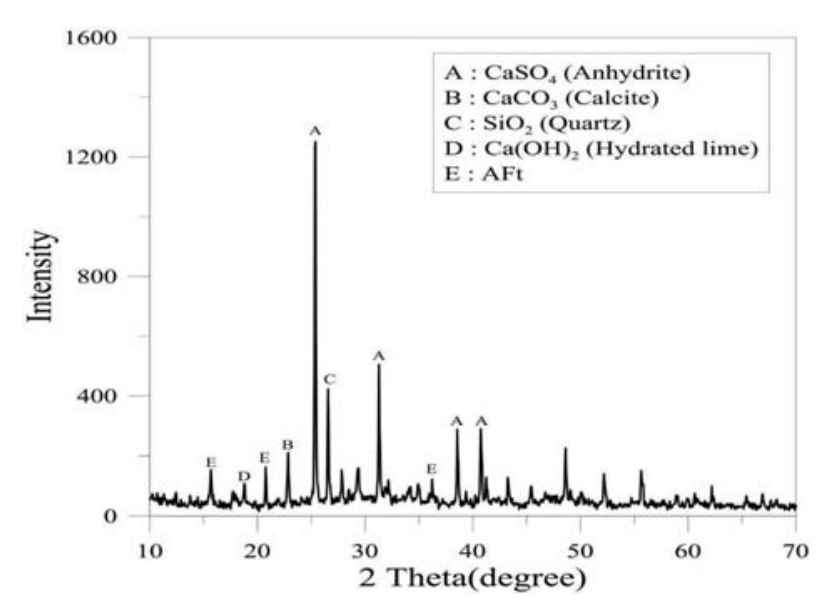

Fig. 10. XRD pattern of A8E mixture.

not conducive and even harmful to binding. In sum, the volume of the voids increased with a higher amount of CFBC ash in the mixture.

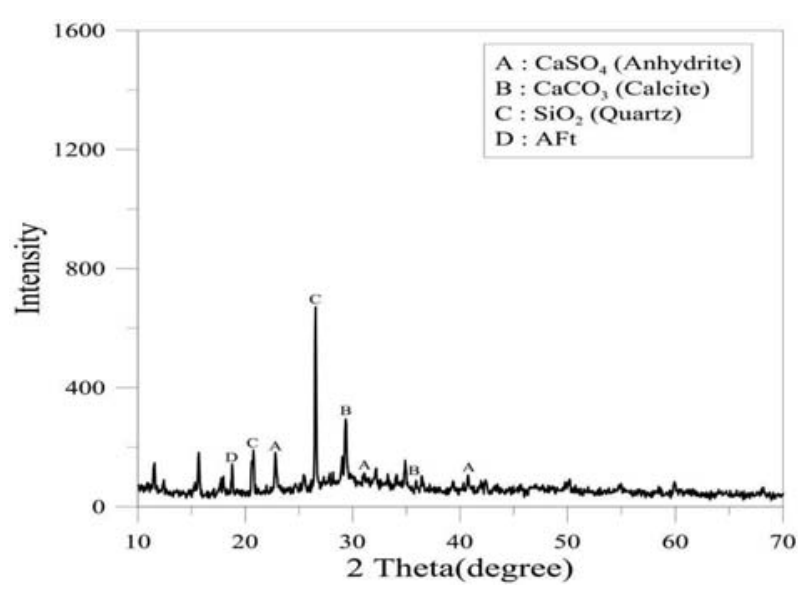

Fig. 11. XRD pattern of B3E mixture.

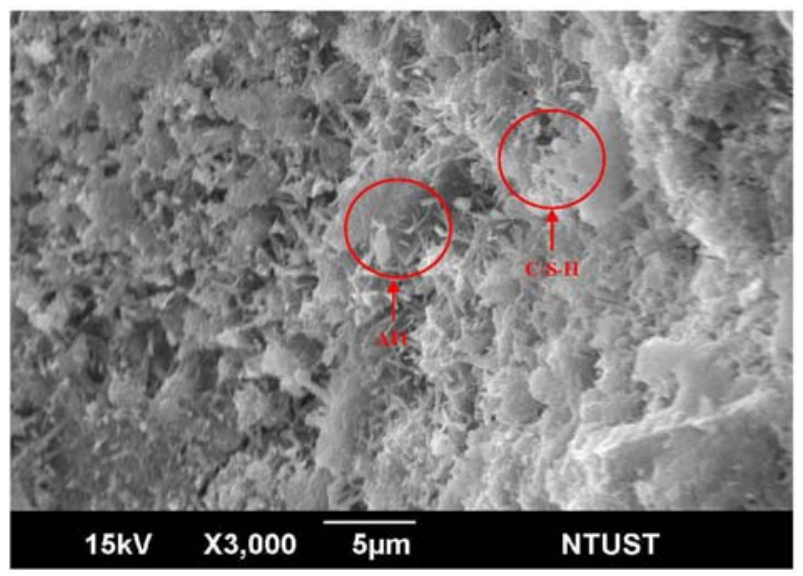

Fig. 12. SEM micrograph of A3E specimen. 


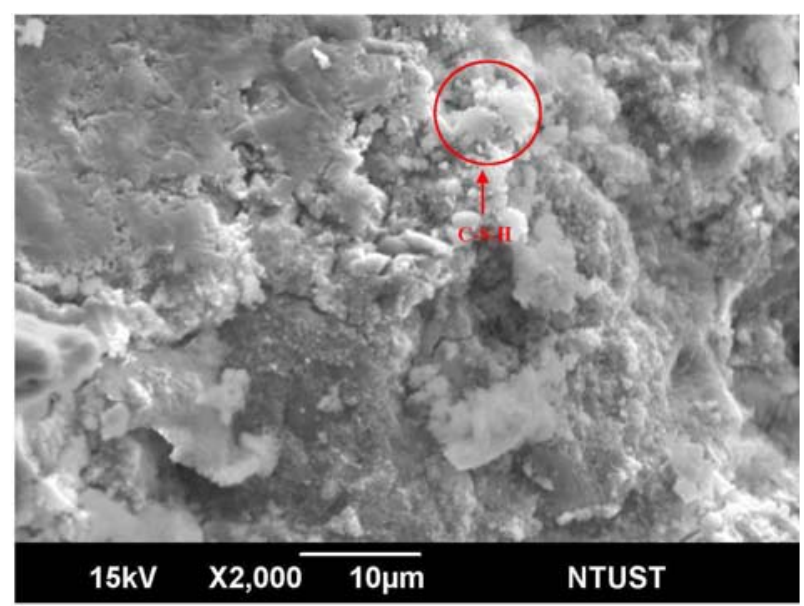

Fig. 13. SEM micrograph of A8E specimen.

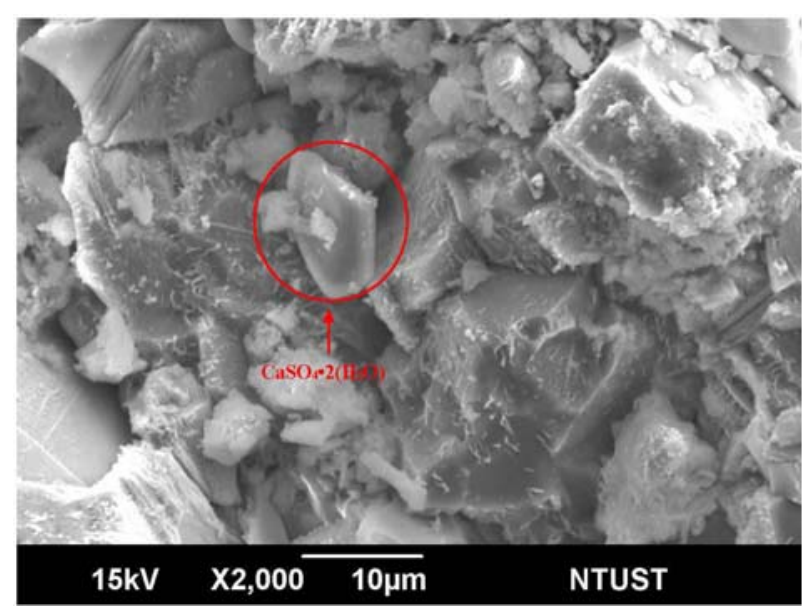

Fig. 14. SEM micrograph of B3E specimen.

\subsection{Shrinkage}

Figure 8 presents the results of the shrinkage test and how they differed with varying curing time and ash-to-GGBFS mass ratios. The mortar samples in which type A ash content exceeded $60 \%$ expanded instead of shrinking after 3 days of curing. However, shrinkage was observed after 28 days. This is explained as follows: The main hydration product in the type A ash, of which excessive amounts were added, was AFt, causing expansion in the early curing stage. However, the poor self-hardening properties and incomplete reaction of the type A ash causes the formation of more inner pores, introducing mortar shrinkage in the late curing stage.

\subsection{X-ray diffraction}

The X-ray diffraction (XRD) results of the hydration products from mixing codes $\mathrm{A} 3 \mathrm{E}, \mathrm{A} 8 \mathrm{E}$, and $\mathrm{B} 3 \mathrm{E}$ are shown in Figs. 9-11, respectively. The analysis revealed the presence of $\mathrm{CaSO}_{4}, \mathrm{CaCO}_{3}$, and $\mathrm{SiO}_{2}$, from which $\mathrm{C}-\mathrm{S}-\mathrm{H}$ gel and $\mathrm{CaSO}_{4} \cdot 2 \mathrm{H}_{2} \mathrm{O}$, the hydration products of GGBFS, are derived. AFt, a source of compressive strength, was also detected.

\subsection{Scanning electron microscopy and energy- dispersive X-ray spectroscopy}

The scanning electron microscopy (SEM) results of the hydration products from $\mathrm{A} 3 \mathrm{E}, \mathrm{A} 8 \mathrm{E}$, and $\mathrm{B} 3 \mathrm{E}$ are presented in Figs. 12-14, respectively. The micrographs revealed that the following hydration products formed:

Table 8. EDX analyzation of A3E and cement grout (\%).

\begin{tabular}{|c|c|c|}
\hline Chemical & A3E & Cement grout \\
\hline C & 10.9 & 0 \\
\hline $\mathrm{O}$ & 47.6 & 51.3 \\
\hline $\mathrm{Mg}$ & 3.0 & 0.7 \\
\hline $\mathrm{Al}$ & 4.5 & 1.3 \\
\hline $\mathrm{Si}$ & 11.2 & 9.1 \\
\hline S & 3.4 & 1.5 \\
\hline $\mathrm{Ca}$ & 18.2 & 31.3 \\
\hline $\mathrm{Zr}$ & 1.1 & 0 \\
\hline K & 0 & 0.7 \\
\hline $\mathrm{Pt}$ & 0 & 4.0 \\
\hline
\end{tabular}


(1) $\mathrm{C}-\mathrm{S}-\mathrm{H}$ gel phases typically formed as fibrous or branched spherical crystals. (2) AFt phases typically formed as elongated acicular or elongated branched acicular crystals. (3) $\mathrm{CaSO}_{4} \cdot 2 \mathrm{H}_{2} \mathrm{O}$ phases typically formed as acicular or prismatic crystals $[17,28]$.

In a comparison of Figs. 13 and 14, the reason the block parts increased in number may be the increasing amount of CFBC ash that was added, which caused incomplete reactions that loosened the structure. In a comparison of Figs. 13 and 14, the use of finer CFBC ash resulted in fewer block parts, indicating a denser overall structure.

The A3E paste and pure cement grout were subjected to energy-dispersive X-ray spectroscopy (EDX) to determine the calcium-to-silicon ratio of the hydration products. The water-to-solid ratio for these two binder systems was maintained at the same value. The A3E paste and pure cement grout (type I Portland cement + water) was cured at $35^{\circ} \mathrm{C}$ and $50 \%$ relative humidity for 32 days. The EDX analysis was conducted after curing was complete.

As shown in Table 8, the calcium-to-silicon ratio of A3E was approximately 1.63, which was lower than that of pure cement grout (3.43). According to [11], a lower calcium-to-silicon ratio of the hydration product $(\mathrm{C}-\mathrm{S}-\mathrm{H}$ gel) is associated with better physicochemical properties and mechanical performance.

\section{Conclusions}

The results indicate that the combination of GGBFS and CFBC can replace Portland cement in concrete as a cementitious material. Increasing the curing temperature is an effective and efficient method to increase the compressive strength of the mixture. A high temperature improves the dissolution of CFBC ash in water and expedites the GGBFS hydration process. An increase in curing temperature from $25{ }^{\circ} \mathrm{C}$ to $35{ }^{\circ} \mathrm{C}$ enabled the compressive strength of the mortar to reach $33.7 \mathrm{MPa}$ after 1 day of curing. The particle size of the activator also affected compressive strength (A3E: $60.8 \mathrm{MPa}, \mathrm{B} 3 \mathrm{E}$ : $32.1 \mathrm{MPa}$ [after 28 days]) and absorption (A3E: $16.5 \%$, B3E: $26.6 \%$ ). Compressive strength and absorption were higher and lower, respectively, when finer CFBC ash was used. The reverse was observed when coarser CFBC ash was used. This is because finer $C F B C$ ash has a larger specific surface area and dissolves more quickly in water, accelerating the GGBFS hydration process. CFBC ash has poor selfhardening properties. Only a limited amount of CFBC ash should be added to activate the GGBFS hydration process and facilitate binding. Notably, the compressive strength of the mortar after 28 days of curing was $60.8 \mathrm{MPa}$ when $30 \%$ CFBC ash was added. However, the compressive strength was lower $(32.6 \mathrm{MPa})$ when $80 \%$ CFBC ash was added. To maximize compressive strength, the mass ratio of type A CFBC ash and GGBFS is 3:7. The mixtures exhibited considerable shrinkage in the early curing stages. However, early strength development also compensated for the adverse effects of shrinkage strain. XRD and SEM indicated that the hydration products of the mixtures included $\mathrm{C}-\mathrm{H}-\mathrm{S}$ gel, $\mathrm{AFt}$, and gypsum, which contributed to the comparable cementitious properties of the mixtures to those of Portland cement. In sum, the mixture of GGBFS and CFBC ash constitutes an ecologically friendly hydration system.

\section{Data availability statements}

Some or all data, models, or code generated or used during the study are available in a repository or online in accordance with funder data retention policies (Provide full citations that include URLS or DOIs.)

\section{References}

[1] ACI (American Concrete Institute). Cement and concrete terminology. ACI116R-00. Farmington Hills, IL: BOCA; 2000.

[2] Anthony EJ, Jia L, Wu Y. CFBC ash hydration studies. Fuel 2005;84:1393-7.

[3] ASTM. Standard test method for drying shrinkage of mortar containing hydraulic cement. West Conshohocken, PA: ASTM C596-09; 2009.

[4] ASTM. Standard test method for density, absorption, and voids in hardened concrete. West Conshohocken, PA: ASTM C642-13; 2013.

[5] ASTM. Standard test method for compressive strength of hydraulic cement mortars (using 2-in. Or [50-mm] cube specimens). West Conshohocken, PA: ASTM C109-16; 2016.

[6] Bellmann F, Stark J. Activation of blast furnace slag by a new method. Cement Concr Res 2009;39:644-50.

[7] Conn RE, Sellakumar K, Bland AE. Utilization of CFB fly ash for construction applications. In: Proceedings of the 15th international conference on fluidized bed combustion, savannah, Georgia; 1999.

[8] Dai X, Aydin S, Yardimci MY, Lesage K, Schuutter GD. Effects of activator properties and GGBFS/FA ratio on the structural build-up and rheology of AAC. Cement Concr Res 2020;138:106253.

[9] Duxson P, Provis JL, Lukey GC, Van Deventer JSJ. The role of inorganic polymer technology in the development of "green concrete". Cement Concr Res 2007;37(12):1590-7.

[10] Erfanimanesh A, Sharbatdar MK. Mechanical and microstructural characteristics of geopolymer paste, mortar, and concrete containing local zeolite and slag activated by sodium carbonate. J Build Eng 2020;32:101781.

[11] Escalante-Garcia JI, Mendoza G, Sharp JH. Indirect determination of the $\mathrm{Ca} / \mathrm{Si}$ ratio of the C-S-H gel in Portland cements. Cement Concr Res 1999;29(12):1999-2003.

[12] Habert G, Ouellet-Plamondon C. Recent update on the environmental impact of geopolymers. RILEM Tech Lett 2016;1:17-23. 
[13] Hansen W, Pressler E. Solubility of $\mathrm{Ca}(\mathrm{OH}) 2$ and $\mathrm{CaSO} 4$ $2 \mathrm{H} 2 \mathrm{O}$ in dilute alkaline solutions. Ind Eng Chem 1947;39: $1280-2$.

[14] Hooey L, Riesbeck J, Wikström JO, Björkman B. Role of ferrous raw materials in the energy efficiency of integrated steelmaking. ISIJ Int 2014;54:596-604.

[15] Huynh TP, Vo DH, Hwang CL. Engineering and durability properties of eco-friendly mortar using cement-free SRF binder. Construct Build Mater 2018;160:145-55.

[16] Hwang CL, Yehualaw MD, Vo DH, Huynh TP. Development of high-strength alkali-activated pastes containing high volumes of waste brick and ceramic powders. Construct Build Mater 2019;218:519-29.

[17] Jeong Y, Oh JE, Jun Y, Park J, Ha J-H, Sohn SG. Influence of four additional activators on hydrated-lime $[\mathrm{Ca}(\mathrm{OH}) 2]$ activated ground granulated blast-furnace slag. Cement Concr Compos 2016;65:1-10.

[18] Juenger MCG, Siddique R. Recent advances in understanding the role of supplementary cementitious materials in concrete. Cement Concr Res 2015;78:71-80.

[19] Juenger MCG, Winnefeld F, Provis JL, Ideker JH. Advances in alternative cementitious binders. Cement Concr Res 2011; 41:1232-43.

[20] Khan MNN, Kuri JC, Sarker PK. Effect of waste glass powder as a partial precursor in ambient cured alkali activated fly ash and fly ash-GGBFS mortars. J Build Eng 2020; 34:101934.

[21] Khan MSH, Kayali O, Troitzsch U. Effect of $\mathrm{NaOH}$ activation on sulphate resistance of GGBFS and binary blend pastes. Cement Concr Compos 2017;81:49-58.

[22] Lee CY, Lee HK, Lee KM. Strength and microstructural characteristics of chemically activated fly ash-cement systems. Cement Concr Res 2003;33(3):425-31.

[23] Li Y, Nie L, Hu XK, Yue G, Li WK, We Y, et al. Structure and performance of a $600 \mathrm{MW}$ supercritical CFB boiler with water cooled panels. In: Proceedings of the 20th international conference on fluidized bed combustion. vol. 1. Xi'an (China): Tsinghua University Press; 2009. p. 132-6.

[24] Li Z, Liang X, Chen Y, Ye G. Effect of metakaolin on the autogenous shrinkage of alkali-activated slag-fly ash paste. Construct Build Mater 2021;278:122397.
[25] Mengasini L, Mavroulidou M, Gunn MJ. Alkali-activated concrete mixes with ground granulated blast furnace slag and paper sludge ash in seawater environments. Sustain Chem Pharm 2021;20:100380.

[26] Nguyen HA, Chang TP, Shih JY, Chen CT, Nguyen TD. Influence of circulating fluidized bed combustion (CFBC) fly ash on properties of modified high volume low calcium fly ash (HVFA) cement paste. Construct Build Mater 2015;91: 208-15.

[27] Park H, Jeong Y, Jeong J-H. Strength development and hydration behavior of self-activation of commercial ground granulated blast-furnace slag mixed with purified water. Materials 2016;9(3):185.

[28] Poon CS, Kou SC, Lam L, Lin ZS. Activation of fly ash/ cement systems using calcium sulfate anhydrite (CaSO4). Cement Concr Res 2001;31(6):873-81.

[29] Schneider M, Romer M, Tschudin M, Bolio H. Sustainable cement production- present and future. Cement Concr Res 2011;41:642-50.

[30] Shahmansouri AA, Nematzadeh M, Behnood A. Mechanical properties of GGBFS-based geopolymer concrete incorporating natural zeolite and silica fume with an optimum design using response surface method. J Build Eng 2021;36: 102138.

[31] Sheng GH, Li QP, Zhai JP. Investigation on the hydration of CFBC fly ash. Fuel 2012;98:61-6.

[32] Shi C, Qian J. High performance cementing materials from industrial slags - a review. Resour Conserv Recycl 2000; 29(3):195-207.

[33] Sievert T, Wolter A, Singh NB. Hydration of anhydrite of gypsum (CaSO4.II) in a ball mill. Cement Concr Res 2005; 35(4):623-30.

[34] Suresh D, Nagaraju K. Ground granulated blast slag (GGBS) in concrete - a review. IOSR-JMCE. 2015;12:76-82.

[35] Thomas RJ, Ye H, Radlinska A, Peethamparan S. Alkaliactivated slag cement concrete. Concr Int 2016;28:33-8.

[36] Voinovitch IA, Dron R. Effect of various activators on the hydration of granulated slag. Silic Ind 1976;41(9):209-12.

[37] Zabihi SM, Tavakoli HR. Evaluation of monomer ratio on performance of GGBFS-RHA alkali-activated concretes. Construct Build Mater 2019;208:326-32. 